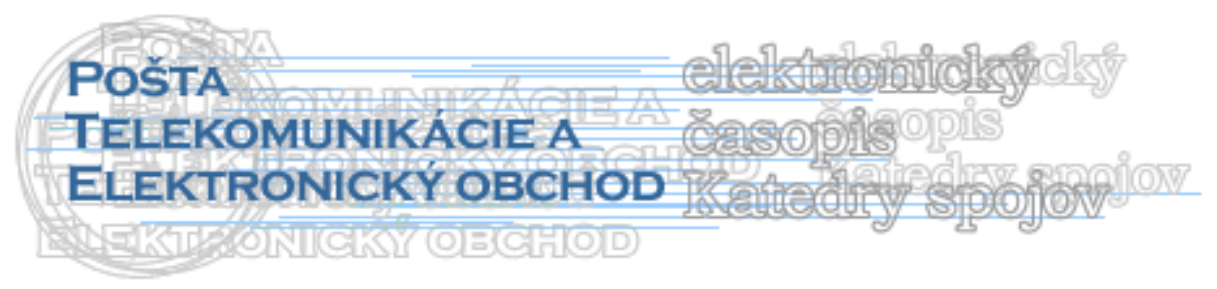

\title{
EARNED VALUE MANAGEMENT
}

\author{
Ing. Martina Kováčiková *
}

\section{Úvod}

Manažment hodnoty prínosu je prístupom, ktorý sa používa v riadení a kontrole nákladov a harmonogramov projektu.

Manažment hodnoty prínosu je praktický koncept, ktorý odporúča, aby všetky projekty bez ohl'adu na ich vel'kost' boli presne definované, naplánované, rozvrhnuté a v súlade $\mathrm{s}$ rozpočtom.

\section{Využitie štandardných nástrojov návrhu a riadenia projektov}

Pri návrhu projektov s využitím metód projektového riadenia sa projekt rozčlení na hlavné skupiny a podskupiny prác - WBS štruktúra - a jednotlivé činnosti sa ohodnotia predpokladanou dížkou trvania a zdrojmi, ktoré ich budú realizovat'. Súčasne sa vytvoria logické väzby medzi následnost'ou činností a tak sa vytvorí „,pavučina“ prepojených činností. Táto umožňuje priebežné sledovanie skutočného postupu projektu ako po stránke časovej, tak aj nákladovej. Pri sklzoch je jeho dopad okamžite premietnutý do celej štruktúry projektu a umožňuje dynamicky prijímat’ rozhodnutia zabezpečujúce úspešnú realizáciu projektu.

Takýchto nástrojov je v súčasnosti značné množstvo. V SR, ale aj v zahraničí je najrozšírenejšie: MS Project, Primavera, Artemis. Pre komplexné riadenie projektov bolo vyvinuté rad metód, ktoré zabezpečujú jeho efektívne riadenie. Medzi najvýznamnejšie patrí metóda „Earned Value“. Metóda je štandardizovaná a široko využívaná. Umožňuje v danom časovom okamihu analyzovat' skutočné, plánované a tiež kalkulované náklady za práce, ktoré boli uskutočnené. Takýto postup umožňuje predvídat' tiež vývoj projektu a prijat' opatrenia, na jeho úspešnú realizáciu, v krajnom prípade i na jeho zastavenie.

Uvedená metóda je štandardne využívaná v NATO pri zadávaní projektov pre vývoj špeciálnej techniky, ale aj napr. bankovým sektorom v zahraničí, pre zabezpečenie priebežnej kontroly realizácie projektu a tým aj návratnosti pôžičiek. Samozrejmým predpokladom je však využívanie vhodného počítačového nástroja riadenia projektu.[1]

\section{Koncepčné riešenie projektu}

Manažment hodnoty prínosu (d’alej len EVM) má jediné zameranie: nepretržité meranie aktuálnych výsledkov oproti podrobnému harmonogramu činností tak, aby bolo

\footnotetext{
* Ing. Martina Kováčiková, Katedra spojov, Fakulta prevádzky a ekonomiky dopravy a spojov, Žilinská univerzita v Žiline, Univerzitná 1, 01026 Žilina, Slovenská republika, tel: +421415133106, fax: +421415655615, e-mail: Martina.Kovacikova@fpedas.utc.sk
} 
možné predpovedat' celkové náklady a dosiahnuté plánované výsledky pre projekt. Inými slovami stanovuje: čo máme za to, čo sme investovali.[2]

Základy koncepcie EVM tvoria nasledovné činnosti:

- definovanie všetkých činností, ktoré majú byt' vykonané v rámci projektu od ich zahájenia po dokončenie,

- zjednotenie projektového rozsahu práce, harmonogram a plánované náklady zaznamenat' do základnej čiary oproti všetkým meratel'ným výsledkom,

- objektívne stanovenie ciel’ov na úrovni pracovnej náročnosti,

- analyzovanie významných odchýlok a ukazovatel'ov od plánu a odhadnút' ich dôsledky,

- poskytovanie údajov na najvyššej úrovni, pre rozhodovanie manažmentu a realizácie.

Systémy riadenia projektu, vrátane EVM, nemôžu sami o sebe zabránit' prekročeniu nákladov a porušeniu harmonogramu, pretože toto môžu urobit' len l'udia v projekte. EVM poskytuje tímu riadenia projektu včasné signály varovania a umožňuje im prijat' nevyhnutné opatrenia. Také výstražné signály, ktoré sa stávajú prístupné už po dosiahnutí 15 až 20 percent v projekte, poskytujú manažmentu dostatok času, potrebného na prijatie opatrení za účelom dosiahnutia priaznivejšieho výsledku. EVM je jednou z niekol'kých metód riadenia projektu, používanou na špecifikáciu, plánovanie a kontrolu projektu.

Metóda EVM vyžaduje nepretržité porovnávanie plánovaných nákladov pre plánovanú prácu (Budgeted Cost for Work Scheduled [BCWS], budget), skutočných nákladov vykonanej práce (Actual Cost of Work Performed [ACWP], costnad) a plánovaných nákladov za vykonanú prácu (Budgeted Cost for Work Performed [BCWP], earned value). EVM umožňuje výpočet rozdielov nákladov a času, založený na skutočne vykonanej práci a nie len spotrebovanými nákladmi počas určitého obdobia bez ich porovnania s prácou, ktorá bola dokončená.[3]

\section{Proces práce s EVM v projekte}

Proces obsahuje 19 krokov, každý vrátane parametrov zodpovedností, účastníkov, účelu, výkazu, vstupu a výstupu. Kroky 1-7 sa realizujú v plánovacej fáze projektu, alebo ked' sa menia zmluvné podmienky rozsahu projektu. Kroky 8-19 sa vykonávajú v realizačnej fáze projektu.

\section{Návrhy procesov EVM vo fáze plánovania projektu}

Návrhy procesov EVM vo fáze plánovania projektu, alebo zmeny jeho zmluvného rozsahu sú stručne charakterizované nasledovne. Každý proces je popísaný jednotným definovaním:

Zodpovednost' - rola, alebo pozícia osoby v projekte, zodpovednej za daný proces,

Účastníci - role, alebo osoby v projekte, ktoré vykonávajú úlohy v danom procese,

Vstup - dokument s podkladmi, ktoré slúžia ako vstup (input) pre daný proces,

Ciel' - špecifikácia požadovaného dosiahnutého výsledku procesu,

Početnost' - perióda opakovania procesu v EVM (týždeň, mesiac, ...), špecifická pre konkrétny projekt,

Výstup - očakávaný výsledok (output) procesu, ktorý z pravidla slúži ako vstup pre iný, alebo d'alší proces, hlásené.

Správa - role, alebo osoby v projekte, ktorým sú výstupy procesu poskytované, alebo 
Procesy vo fáze plánovania projektu, alebo zmeny jeho zmluvného rozsahu sú nasledovné:

1. Analýza projektu

2. Štruktúra činností projektu

3. Organizačná štruktúra projektu

4. Matica zodpovedností

5. Časový odhad prác

6. Harmonogram projektu

7. Rozpočet nákladov projektu (BCWS - plánované náklady pre plánovanú prácu)

\section{Návrh procesov vo fáze realizácie projektu}

Návrhy procesov EVM vo fáze realizácie projektu, alebo zmeny jeho zmluvného rozsahu, sú stručne charakterizované nasledovne v krokoch 8 až 19

8. Skutočné náklady za vykonanú prácu (ACWP) za každú skupinu činností (oblast')

9. Skutočné náklady za vykonanú prácu (ACWP) za projekt

10. Postup práce za každú skupinu činností (oblast')

11. Hodnota prínosu (BCWP) pre každú skupinu činností (oblast')

12. Hodnota prínosu (BCWP) za projekt

13. Analýza skupín činností

14. Návrh opatrení pre skupiny činností

15. Analýza vývoja projektu

16. Rozhodnutie o opatreniach

17. Realizácia opatrení

18. Vyhodnocovanie činností

19. Ukončenie skupín činností

\section{Hodnota prínosu}

Hodnota prínosu pre každú oblast' resp. skupinu činností.

\section{Spôsoby merania hodnoty prínosu}

Manažér projektu musí zvolit' metódu, ktorá je vhodná pre charakter skupiny činností. Je dôležité, aby bol odhad dokončenia práce urobený správnym spôsobom, preto musí odhad schválit' zodpovedný manažér projektu.

Váhové míl'niky - skupiny činností sú rozdelené do niekol'kých míl'nikov, ktoré sa používajú pre meranie priebehu. Každý míl'nik získava hodnotu rozpočtu, ktorá bude dosiahnutá, ked' budú dokončené, dodané a dosiahnuté všetky jeho ciele. Jednoduchšie sa meria dosiahnutá hodnota $\mathrm{v}$ míl'nikoch, ktoré sú založené na dokončení fyzického produktu. Táto metóda je vel’mi náročná na plánovanie, administráciu a vyžaduje si vel’a času pre jednania medzi manažérom projektu ,manažérmi organizácie a členmi projektu, ktorí budú prácu vykonávat'. Metóda je vhodná, ak skupiny činností trvajú dlhšie ako tri mesiace. V opačnom prípade je náročné rozdelit' kratšiu skupinu činností vhodným spôsobom.

Pevný vzorec: Hodnota prínosu zahájenia / Hodnota prínosu dokončenia - táto metóda je možno jednoduchšia na pochopenie, ale vyžaduje si použitie vel'mi detailizovanú a krátkodobú skupinu činností. Najčastejšie hodnoty sú $0 / 100,50 / 50,25 / 75$, ale môžu byt' zvolené aj iné hodnoty. Hodnota 50/50 napríklad znamená, že skupina činností získala 
hodnotu prínosu 50\% z rozpočtovanej hodnoty, ked' bola zahájená a zostávajúcich $50 \%$ po jej dokončení.

Percentuálny odhad dokončenia - je to subjektívny odhad, ktorý umožňuje urobit' odhad v časových úsekoch založených napríklad na týždňoch, alebo mesiacoch. Táto metóda je l'ahká pre administráciu a je vhodná, ak boli dobre špecifikované skupiny činností. Maximálna hranica vloženej hodnoty je $80 \%$, lebo $90 \%$ pre skupinu činností dovtedy, kým dosiahne $100 \%$. Pri použití tejto metódy musia byt' odhady kontrolované, aby neboli príliš optimistické.

Kombinácia percentuálneho odhadu dokončenia s váhovými míl’nikmi - táto metóda spája to najlepšie z odhadov percentuálneho dokončenia s váhovými míl'nikmi. L’ahké používanie subjektívneho percentuálneho odhadu dokončenia s míl'nikmi ako kontrolnými bránami. Odhady nemôžu presahovat' míl'niky skôr, ako sú dosiahnuté a dokončené ich ciele.

\section{Hodnota prínosu za projekt}

Zhromaždenie a súhrn informácii hodnôt prínosov z jednotlivých skupín činností poskytuje manažérovi projektu informácie pre predpoved' pravdepodobného dokončenia a priebehu harmonogramu projektu.

Dôvodom možného odhadu časovej náročnosti pre dokončenie projektu je schopnost' manažéra projektu porovnat' priebeh prác za skupiny činností oproti kritickej ceste v projekte.

\section{Záver}

EVM je zlepšením tradičného porovnávania medzi predbežnou kalkuláciou a skutočnými nákladmi za účelom sledovania vývoja v projekte. EVM sa zameriava na vzájomný vzt'ah medzi vynaloženými skutočnými nákladmi, oproti skutočne realizovaným prácam v projekte, pre schopnost' získania ekonomickej hodnoty vykonanej práce, tzn. hodnoty prínosu. EVM vyžaduje jednotnú metódu pre analýzy a poskytuje podklady pre analýzu efektívnosti nákladov v projekte. Riadenie projektu získava lepšiu kontrolu a prehl’ad o vývoji projektu.

\section{Literatúra}

[1] KOVÁČIKOVÁ, M.: 2004 Písomná práca k dizertačnej skúške - Vplyv informačného systému na riadenie l'udských zdrojov organizácie, ŽU v Žiline

[2] DEPARTMENT OF DEFENCE, (1998), Mandatory procedures for Major Defence Acquisition Programs (MDaPs) and Major Automated Informations System (MAIS) Acquisition Programs, Appendix VI, DoD Regulation 5000.2-R, Internet, 13.12.1999, http://www.acq.osd.mil/sa/asm/5002c3.doc

[3] HTPP://WWW.IFSWORLD.COM

Príspevok vznikol na základe riešenia výskumného projektu VEGA 12/2591/05 Vplyv výberu efektívnej stratégie na udržiavanie konkurencie schopnosti podniku $\mathrm{v}$ rámci liberalizácie poštových trhov, podporeného MŠ SR 